Title:

Author(s):

Submitted to:
Performance Monitoring for Plume Remediation and Containment Actions

\section{RECEIVED}

SEP 231996

Pat Unkefer, CST-18

James Herrick, CST-18
OSTI
DOE Office of Scientific and Technical Information (OSTI)

\section{Los Alamos}

NATIONAL LABORATORY

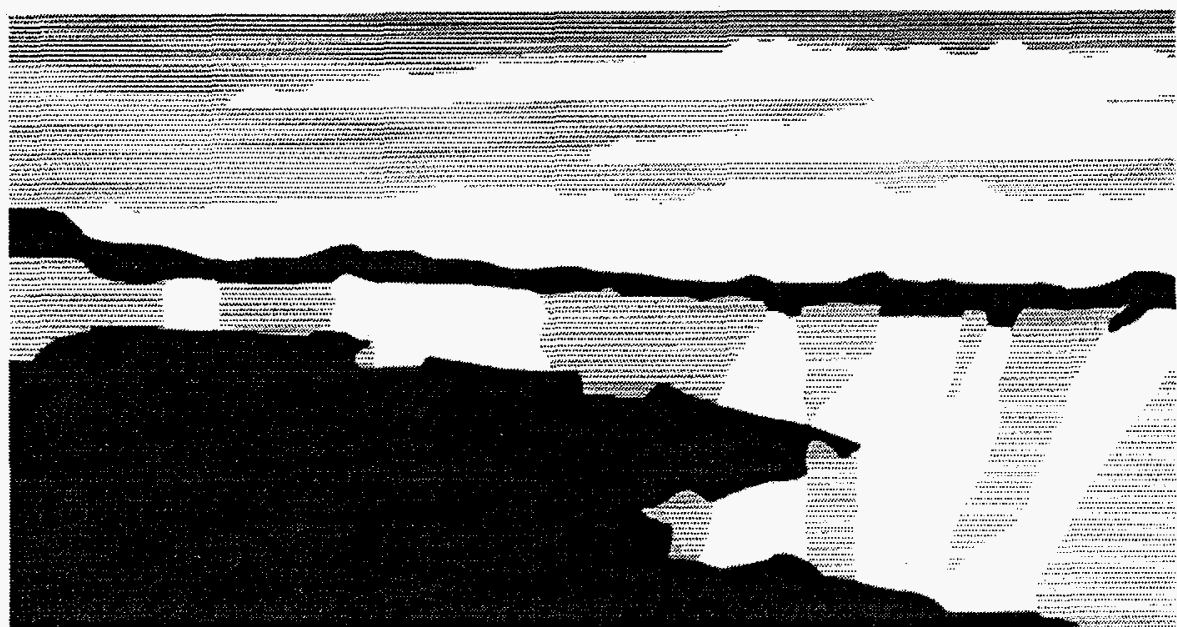

Los Alamos National Laboratory, an affirmative action/equal opportunity employer, is operated by the University of California for the U.S. Department of Energy under contract W-7405-ENG-36. By acceptance of this article, the publisher recognizes that the U.S. Government retains a nonexclusive, royaltyfree license to publish or reproduce the published form of this contribution, or to allow others to do so, for U.S. Government purposes. The Los Alamos National Laboratory requests that the publisher identify this article as work performed under the auspices of the U.S. Department of Energy. 


\section{DISCLAIMER}

Portions of this document may be illegible in electronic image products. Images are produced from the best available original document. 


\section{DISCLAIMER}

This report was prepared as an account of work sponsored by an agency of the United States Government. Neither the United States Government nor any agency thereof, nor any of their employees, makes any warranty, express or implied, or assumes any legal liability or responsibility for the accuracy, completeness, or usefulness of any information, apparatus, product, or process disclosed, or represents that its use would not infringe privately owned rights. Reference herein to any specific commercial product, process, or service by trade name, trademark, manufacturer, or otherwise does not necessarily constitute or imply its endorsement, recommendation, or favoring by the United States Government or any agency thereof. The views and opinions of authors expressed herein do not necessarily state or reflect those of the United States Government or any agency thereof. 


\title{
Performance Monitoring for Plume Remediation and Containment Actions
}

\author{
Pat Unkefer* and James Herrick
}

\begin{abstract}
This is the final report of a one-year, Laboratory-Directed Research and Development (LDRD) project at the Los Alamos National Laboratory (LANL). Bioremediation is a promising alternative to conventional cleanup technologies because of its relative speed, safety, and cost. However, current methods for measuring and evaluating the performance of bioremediation are inadequate. The development of the basic understanding and methods for assessing bioremediation performance are a key goal for future long-term research at bioremediation research sites. This project sought to develop an improved understanding of the pathways and genes employed by bacteria in the catabolism of pollutants in actual field situations.
\end{abstract}

\section{Background and Research Objectives}

Current chemical methodologies for assessing biodegradation rates are labor intensive, expensive, and usually provide very indirect measures of in situ bioremediation processes. The need for better performance assessment methods for in situ remediation has been called out by practically every workshop on remediation needs [1-4]. Despite this need, the development and demonstration of innovative methods for performance assessment are not proceeding rapidly. A recently published evaluation of in situ bioremediation suggests that demonstration that in situ bioremediation is working should include three types of evidence: (1) documentation of loss of contaminant from the site, (2) laboratory assays showing that microorganisms isolated from the site can degrade the contaminants under conditions similar to those found at the site, and (3) one or more epics of evidence that the biodegradative potential demonstrated in (2) is actually realized in the field. Obtaining evidence to document contaminant loss and biodegradative potential in the laboratory has been achievable; it is demonstrating that the potential is realized under actual field conditions that has been difficult.

\footnotetext{
* Principal investigator, e-mail: punkefer@lanl.gov
} 
An improved understanding of the pathways and genes employed by bacteria in the catabolism of pollutants in actual field situations will: (a) improve our confidence in extrapolating genetic and physiological information from the laboratory to contaminated field sites, (b) provide a basis for testing whether suspected biodegradative processes are actually occurring at field sites, (c) aid in predicting the fate of pollutants, and (d) assist in the development of inoculants for bioremediation. One of the most promising methods that has been proposed for demonstrating the biodegradative capability in the field is the use of polymerase chain reaction (PCR) based methods to show the presence of genes encoding the biodegradative proteins or the transcripts of those genes. Although these molecular techniques are very sensitive and widely applicable, they are subject to the criticism that the presence of the gene, or even a transcript, does not necessarily mean that the biodegradative enzymes are active. It was the goal of this project to determine if the catabolic potential of toluene-degrading bacteria (as measured by the presence of toluene pathway-specific genes) accurately reflected the actual catabolic activity taking place at a field site (as determined by the direct detection of toluene catabolic intermediates).

An extension of our approach incorporates the use of stable isotopically labeled contaminants as tracers and mass spectrometry detection to determine quantitatively the fates of contaminants in the environment. Advantages of this approach over alternate approaches for measuring remediation performance are numerous. The use of stable isotopes and mass spectrometry does not require a priori knowledge of the different fates of the contaminant. Expected and unexpected products of contaminant transformation are detected with high sensitivity. The use of stable isotopes and mass spectrometry represents the most practical way to determine mass balance in the field. Even for cases where complete mass balance cannot be achieved, the use of stable isotope tracers allows detection of the absence of mass balance and unambiguous identification and quantitation of a larger subset of potential disappearance mechanisms than any other strategy proposed to date.

\section{Importance to LANL's Science and Technology Base and National R\&D Needs}

This project supports Los Alamos core competencies in bioscience and biotechnology as well as earth and environmental systems. The research will directly benefit the nation by speeding the use of new and innovative remediation technologies and reducing the uncertainty associated with their use. 


\section{Scientific Approach and Results to Date}

This project has focused on developing robust methods for detecting and monitoring bacterial populations that degrade toluene, an EPA priority pollutant. Toluene is catabolized in bacteria by one of five known pathways, each of which utilizes a distinct multicomponent oxygenase enzyme in aromatic ring cleavage. Our objective has been to develop the capability to detect, in both isolates and directly in environmental samples, genetic and metabolic markers of these pathways with the goals of quantifying their relative importance in the field and of detecting possible new pathways for toluene catabolism. We have developed improved PCRbased methods for detecting and distinguishing indigenous toluene degrading bacteria and their toluene catabolic pathways at a gasoline- and diesel- contaminated site at Los Alamos. In addition we have developed microcosm models to validate our molecular and chemical techniques for application at field sites.

\section{References}

1. High Priority on Bioremediation: Bioremediation Needs Workshop, Environmental Protection Agency Office of Research and Development (1991).

2. Gibson, D. T. and G. S. Sayler, editors, "Scientific Foundations of Bioremediation: Current Status and Future Needs," American Academy of Microbiology, Washinton, D.C. (1992).

3. "In situ Bioremediation: When does it Work?," National Research Council, National Academy Press, Washington, D.C.

4. Nelson, C., R. J. Hicks, S. D. Andrews in "Bioremediation: Field Experiences," P. E. Flatman, D. E. Jerger, and J. H. Exner, editors, Lewis Publishers, Chelsea, MI.

\section{Publication}

J. B. Herrick, K. S. Harris, and J. R. Brainard, "Rapid fingerprinting of bacteria using ERIC PCR primers," in PCR: Essential Techniques, Julian F. Burke, ed., Bios Sci. Publ., Oxford, (in press), Los Alamos Report LA-UR 95-2891 (1995). 